\title{
Cultivating Students' Interest and Positive Attitudes towards Indonesian Language through Phenomenon-Text-Based Information Literacy Learning
}

\section{Putu Mas Dewantara}

Universitas Pendidikan Ganesha, Indonesia, mas.dewantara@gmail.com

\section{Nengah Suandi}

Universitas Pendidikan Ganesha, Indonesia, nengah.suandi@undiksha.ac.id

I Wayan Rasna

Universitas Pendidikan Ganesha, Indonesia,wayan.rasna@undiksha.ac.id

\section{Ida Bagus Putrayasa}

Universitas Pendidikan Ganesha, Indonesia,bg.putrayasa@undiksha.ac.id

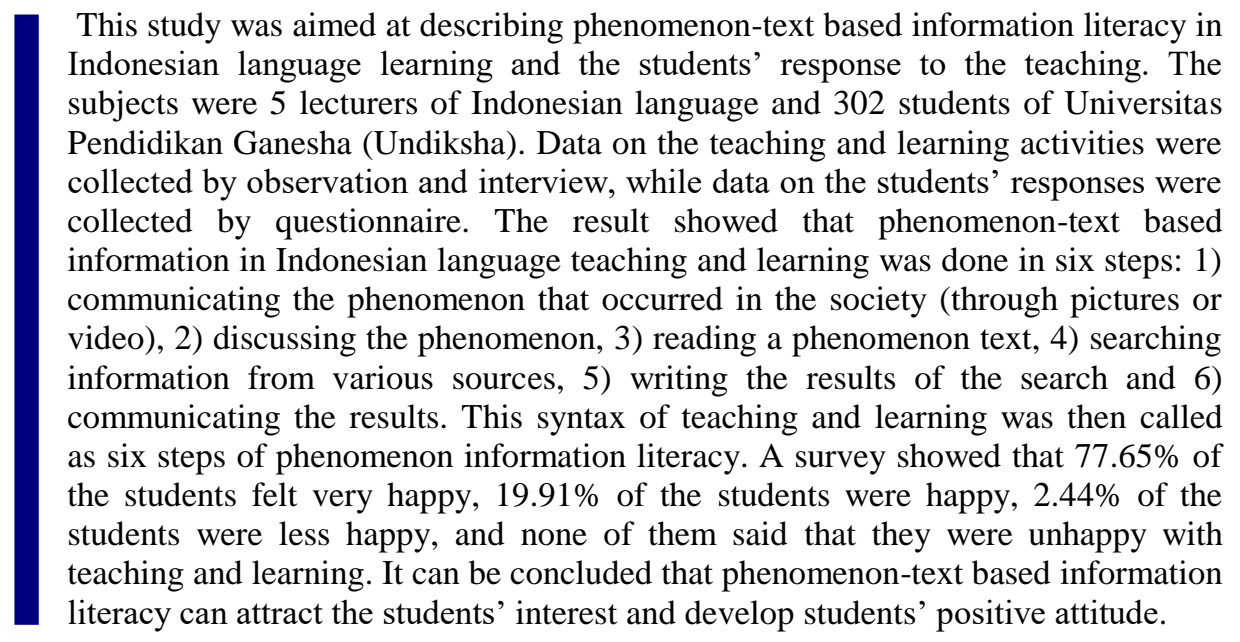

Keywords: information literacy, phenomenon text, Indonesian language learning, attitude

Citation: Dewantara, I. P. M., Suandi, I. N., Rasna, I. W., \& Putrayasa, I. B. (2019). Cultivating Students' Interest and Positive Attitudes towards Indonesian Language through Phenomenon-TextBased Information Literacy Learning. International Journal of Instruction, 12(2), 147-162. https://doi.org/10.29333/iji.2019.12210a 


\section{INTRODUCTION}

The index of Indonesian people who do not have reading interest is only 0.001 . It means that out of 1.000 people, only 1 shows interest in reading (Yulaningsih, 2014). The result of a study conducted by Programme for International Student Assessment (PISA) in 2015 showed that Indonesian students' literacy culture ranks 69th of the students from 76 participating countries (Harian Jogja.com, 2016). The study entitled "Most Littered Nation in the World" conducted by Central Connecticut State Univesity in last March 2016 showed a similar condition, in which Indonesia ranks 60th of 61 countries (Gewati, 2017).

In response to the low student literacy culture in Indonesia, the government issued a regulation through the Regulation of the Minister of Education and Culture No. 23 of 2015 which requires the students to read for 15 minutes before a lesson starts. Based on the regulation, various educational institutions starting from elementary to tertiary educational institutions are starting in the process of and have already developed a 15 minute literacy program before a lesson starts. In tertiary educational institutions, the urgency of the literacy program is very intense for the students and the lecturers. Literacy at a university is regarded as a series of skills that are generic in nature and applicable in all fields of discipline (Hasugian, 2009; Nurohman, 2014).

One of the compulsory courses in a university is Indonesian language. Indonesian Language occupies a strategic position because of its role as penghela (something that pulls) knowledge. It means that, Indonesian language is a medium of instruction. Indonesian language teaching and learning at the university is oriented to develop positive attitudes toward Indonesian Language and ability to use the language correctly and appropriately. Attitude can be defined as positive or negative behaviors developed by a person in relation to objects, a concept or state. Attitudes are not born but they are learned behaviors. Attitudes are gained through direct experience with the object, reinforcement, imitation and social learning (Gelisli et al., 2017). At Universitas Pendidikan Ganesha (Undiksha) the goal is achieved through teaching four language skills: listening, speaking, reading, and writing. It is hoped that Indonesian Language teaching and learning helps the students in collecting, processing, and communicating information. Hence, it is just natural that Indonesian language teaching and learning enables the students to acquire good literacy ability.

In reality, the Indonesian Language teaching and learning at the university level, especially at Undiksha faces some constraints. One of them is the low students' interest in learning Indonesian Language (Dibia, et.al., 2016; Dewantara, 2017). On the other hand, the teaching and learning process will be more meaningful if the students show a high interest in learning (Mustami, et.al., 2018). As a general course, Indonesian Language is viewed as a complementary course. This is also seen from the behavior of the students that shows a rather negative attitude toward Indonesian Language. The students of Undiksha often deviate from a good use of Indonesian both at the word and sentence level (Dewantara, 2017). This deviation is the manifestation of their negative attitude Hence, there is a need for an effort to develop positive interest and attitude One of the ways to do this is through cases or phenomena (Mutmainah, 2008; Hadiya, et.al., 
2015). Thus, phenomenon-based text is a way that needs to be tried to overcome the students' interest and attitude problems. On the one hand, phenomenon text-based literacy trains literacy ability and on the other hand, it is expected that it can develop a positive attitude towards Indonesian language.

Information literacy has attracted attention for a long time. Breivik \& Gee (1989) and Rader (1991) discuss library revolution in relation to information literacy. Bundy (2004) wrote a book on Australian and New Zealand information literacy framework. Ibrahim \& Jimoh (2013) talked about sustainable teacher education in Nigeria through literacy information in the 21 st century. They also talked about the relation between information literacy and library. In Indonesia there are also many people who are interested in the importance of information literacy. Hasugian (2009) gives his opinion on the importance of information literacy in a competence-based curriculum at the university. Balfas (2008) talked about the development of literacy ability and critical thinking through the teaching of context-based literature. Nurohman (2014) sees the significance of information literacy in the global era. Pattah (2014) gave his opinion on the improvement of information competence in teaching. Subandiyah (2015) shares his view on literacy teaching in the teaching of Indonesian language. Such attention to literacy is largely expressed in the form of opinions or in other words there are not many research topics on information literacy.

The study of Apriyani (2006) focused on library goers' information literacy in public libraries in Jakarta Special Region. Latief (2016) studied lecturers' information literacy ability in information search in teaching at STIE Bina Bangsa Serang-Banten. On the other hand, only two studies on literacy in Indonesian Language teaching. First, the study by Gipayana (2016) that focused on literacy teaching and portfolio assessment in the context of the teaching of writing at elementary school. The study showed that literacy teaching and portfolio assessment are recommendable as a superior concept in the teaching of writing at elementary schools. The second study is a study by Yulianita (2014) who studied about the correlation between the implementation of information literacy and task score in Indonesian Language at SMPN 5 Yogyakarta. From the result it was revealed that there is a correlation between information literacy implementation and task score in the students' Indonesian Language task score. From the two studies on literacy in Indonesian Language teaching there are not any studies on phenomenon textbased literacy. Furthermore, neither has there been any study on literacy at the tertiary level. Therefore, this study is new and interesting to be done. This study tried to give a description on how phenomenon-based literacy teaching was done and the students' response to it.

\section{LITERATURE REVIEW}

\section{Information Literacy}

There are many definitions of information literacy and the definitions will continue to develop according to condition of time and the development of science and technology. Information literacy is the ability to understand information, to search and determine information needed, to develop or organize information ethically and to present it to the audience (Bruce, 1997; Hasugian, 2009; Ibrahim \& Jimoh, 2013). Information literacy 
as one of the high order thinking skills that is needed to develop and support academic, professional and personal successes (Shao \& Purpur, 2016). Bruce (2004) states that information literacy is the catalyst for changes in education. The term information literacy used in this paper is defined as what is defined by Bruce (1997), Hasugian (2009), Ibrahim \& Jimoh (2013).

Education can empower all people to obtain information according to their needs. Empowerment of information role is the important objective of education and is a very valuable source (Boyer, 1997). Information will change into knowledge in the teaching and learning process. It has to be kept in mind that to change information into knowledge is not an easy task to do (Hasugian, 2009). To what extent an individual obtains information depends very much on his or her ability to seek, trace, find, and evaluate information from millions of sources and varieties of sources (Nurohman, 2014). From what is obtained a new knowledge will be formed. The quality of a new knowledge that is produced depends on the quality of knowledge obtained through information literacy. Hence, information literacy is important in teaching and learning.

Grafstein (2002) states that some literature argues that information literacy is the core of the objective of education and has to become the main component of the academic curriculum. Information literacy is an issue at every college and university. Colleges and universities are aware of the importance of information literacy done by optimizing all resources through strategies designed to develop literacy ability of the students (OwusuAnsah, 2004).

There has been a lot of researches, which includes Kong (2014) who studied about developing information literacy and critical thinking skills. Nesset (2015) did a research using empirical data to refine a model for information literacy instruction for elementary school students. Folk (2016) studied information literacy in postsecondary education in the United Kingdom, the United States, Australia, and New Zealand. Frau-meigs (2017) even has studied the role of media and literacy in the modern era and introduced the concept of trans literacy for 'Information society'. The development of digital literacy indicators has been made for Thai undergraduate students using mixed method research (Techataweewan \& Prasertsin, 2017). Even literacy, especially media literacy has been used as the media for the empowerment of women in Indonesia (Suwana \& lili, 2017).

There are some models of information literacy known such as Big 6, Seven Pillars, and Empowering 8. The Big 6 developed in U.S.A by two librarians, Mike Eisdenberg and Bob Berkowitz. The Big 6 uses problem solving approach to teach information and information skill and technology. Seven Pillars was developed in UK and conceptual model by SCONUL (Standing Conference of National and University Libraries). While for Southeast and South Asia Empowering Eight (E8) was developed. The literacy model implemented in this study is adjusted to the characteristics of situation and the aim of the literacy is implemented. Hence, the model that is implemented can give variations to the literacy models that existed before.

\section{Text of Phenomena}

A phenomenon is a series of events and forms of condition that can be observed and evaluated through scientific perspective or through a certain discipline. Phenomena 
occur in all places that can be observed by humans. In Kamus Besar Bahasa Indonesia it is explained that the similarities in phenomena are symptoms which mean things or conditions that are unusual and ought to be seen and sometimes indicates that something will occur. Phenomenon texts in this study mean texts that contain information with the characteristic of stimulating students' curiosity, arousing questions, containing new information, even are controversial in nature. In Indonesian language teaching, the use of phenomenon texts to increase interest in learning has never been done before.

The attempt to teach controversial phenomena was made by Oulton, et.al. (2007). According to them, so far the teaching with controversial issues has not produced promising results. According to them, the teaching with controversial issues needs to stress that there is a difference in perspective toward the phenomenon. The difference in perspective is caused by the difference in the way of looking at the information. The controversial phenomenon can be overcome by the increasingly more information available. The teacher has to approach the issues with the spirit of critical inquiry to help the students to explore ideas that are related to the issue of the phenomenon (Byford, et.al., 2009). The finding of Byford et.al. (2009) shows that the phenomenal issue is felt to be important to be taught although it is felt to have the potentiality of limiting the teacher in developing and teaching the phenomenal issues.

Research that used phenomenal texts used to be done in teaching history and was successful in attracting students' attention (Marcus \& Stoddard, 2009; Saefudin, 2013; Abrar, 2015; Sumardiansyah, 2015). The use of texts with dilemmatic and controversial contents to enhance learning achievement has also been done in teaching social science (Prihantoro, 2016; Anda, 2017). The teaching with controversial issue phenomena can make students less certain about their standpoints than when they started to learn (Clarke, 2005). This is due to the fact that they have more information than before having an open attitude by looking at various perspectives about a phenomenon that contains controversial issues (Hand \& Levinson, 2012). Those studies show that the use of phenomenon texts can increase students' interest and learning achievement.

\section{METHOD}

\section{Sample}

The sample of this study consisted of 302 first semester students in the academic year of 2017/2018 distributing in 12 classes. The sample was determined by cluster random sampling technique. This size is a representative size according to Krejcie and Morgan's table at the $5 \%$ level of significance. This study also involved 5 lecturers who taught at the 12 classes.

\section{Research design}

This study used the mixed methods approach. The data were made up of (1) steps of Indonesian Language teaching through phenomenon text-based information literacy, and (2) the students' response to the teaching. Data that were related to the steps of teaching were qualitative data, while data of students' responses were quantitative. This study used sequential mixed method in which interview and observation were used to obtain 
qualitative data, then it was continued with a survey of the students' responses to collect the quantitative data.

\section{Instrument}

There were three methods of data collection used in this study. Observation method was used to know the steps of teaching implemented by the lecturers, questionnaire method to know the students' responses to the teaching, and interview for knowing the constraints faced by the lecturers in implementing the teaching. Thus, the instruments used were observation sheet of the teaching steps, student response questionnaire, and interview guide on teaching constraints. The observation sheet of teaching steps is a completion form on the activities of the lecturer from the beginning to the end of the teaching activity. The student response questionnaire contains statements related to student's interest and language attitude.

The student response questionnaire contains eight statements. The statements are related to student interest as shown by statements numbers $1,2,3,7$, and 8 . The statements 4,5 , and 6 are related to language attitude; that is related to faithfulness, pride, and obedience to the language norm. The instrument of interview guide contains unstructured questions.

All of the instruments in this study were developed according to the needs and were validated and analyzed using Gregory formula by asking help from two experts. The two experts saw the match between the indicators and the instruments developed. The result of the analysis of the three instruments showed that the three instruments are valid and can be used in the study. An empirical test was then done to test the validity and reliability of the student response questionnaire. The empirical test involved 67 students. The result of the validity test with Pearson Product Moment showed that 8 of 10 questionnaire items of student responses are valid. While the result of reliability test using Alpha Cronbach formula yielded a value of 0.736 and when compared to Guilford' s criteria it turned out that the questionnaire has a very high reliability

\section{Data Collection and Data Analysis}

Data analysis in this study used Miles \& Hubermas (1992) qualitative data analysis model. There were four important and inter-related stages: data collection, data reduction, data display, and conclusion drawing or verification. At the first stage data collection was done using observation to collect data on the steps of teaching implemented by the lecturers. In addition, data collection was also done by interview to ask things that needed confirmations from the lecturers. The next data collection was done to know the students' responses to the teaching, i.e, in relation to the students' interest and language attitude after learning. The instrument used to collect the data on these was student response questionnaire that had been validated before. After data collection the next stage was data reduction. At this stage the data were analyzed by doing data reduction. At this stage the data were analyzed to sharpen, classify, orient, remove the data that were not needed by sorting the same data based on the aims of the study. The data were coded to make data selection easy, in which A was used to mark data for the first problem and B for the second problem. 
At the data display, the data were described. The data were described as they were and were sequenced according to the code given before. Then a conclusion was drawn by following the sequence of data display. Conclusion drawing was also done according to data classification that was done before. The data were then interpreted to draw a final conclusion.

\section{FINDINGS}

The result of the study is as follows:

\section{Steps of phenomenon-text-based information literacy in Indonesian Language teaching}

The teaching of Indonesian language using phenomenon-text-based information literacy was done by 5 lecturers to 302 students in 12 classes. In general, from the 12 classes the steps followed by the lecturers are as follows.

\section{1) Communicating problems in the form of phenomena that occurred in the society (See)}

At this stage the activity done by the lecturers aimed at arousing the students' attention to learn. The lecturers maximized the use of the teaching materials in the form of pictures or videos to attract the students' attention and to prepare the students' perception for the topic. This stage is called pre reading (Subandiyah,2017). The result of observation showed that the students were interested in the pictures and or videos presented by the lecturers on the screens. This interest was indicated by the act of focusing on the problem under question. Another strategy used by the lecturers in communicating the problem was by telling a story about a phenomenon that occurred in the society. This strategy follows the strategy of using learning environments to create a conducivve learning atmosphere (Demirci, 2017).

\section{2) Discussing the phenomenon}

The problems communicated using pictures or videos of course will arouse various problems or questions. Thus, the second step taken by the lecturers was discussing the phenomena that occurred with the students. The discussion aimed at helping the students to understand the phenomena. The result of the study done by Memduhoğlu, et. al. (2017) showed that focused group discussion can help the students to improve abilities in facing problems. The students seemed very enthusiastic when a discussion was used. This step has also developed a positive relation between the lecturers and students in learning. Thus, teachers can exercise an enormous influence on the formation of attitudes and behaviors in the class (Gelişli et al., 2017).

\section{3) Reading phenomenon text that the lecturer has prepared}

The next process followed by the lecturers was to distribute phenomenon texts that they have prepared. The students looked very enthusiastic to read the text given. The reading activity was aimed at drawing the students' attention to learn Indonesian. The reading activity at this stage was a critical reading of phenomenon texts. The lectures were seen 
to attempt to provide sufficient time for the students to understand the reading texts. Pujiono (2012) showed that after reading the text and understanding it, the critical reader stores the information in his or her long-term memory. The reading of the text is aimed at developing a positive attitude as what was found about the use of texts that could develop good characters according to what has been targeted (Novianti, 2017).

4) Looking for other information related to the phenomena from various sources (explore)

At this stage, the lecturers assigned the students to find information from various sources that were related to the phenomena in the texts they had read. The result showed that the search for information was done by the students through two ways, i.e., by reading books that had been prepared and by searching information through the internet. The constraints that were faced at this stage were the problem of internet connection which was suddenly disconnected and when the connection was very slow. The strategy to overcome this was by using personal connection from cellular phone hotspots.

At this stage the students were guided again to be able to read texts critically. A critical reader does not only take in information as it is, but also thinks about the problem that he or she is reading (Pronowo \& Herujiyanto, 2015). Critical reading is done by the student analytically and evaluatively. Pujiono (2012) stated that direct or indirect critical reading can cause change in attitude, behavior, and action in daily life. This means that there is a relation between the text, the text reader's attitude, behavior and action.

\section{5) Writing the result of Information Search}

At this stage there were three main activities done: (1) summarizing main ideas from various sources of information, (2) collecting main ideas to form new concepts, and (3) comparing new knowledge and the old one to find an added value obtained. Three activities agree with the last three steps in the seven sets of skills that were developed at universities which were called "The seven Headline skills" by Standing Conference of National and University Libraries (SCONUL) (Bainton, 2001). In its implementation at Undiksha, there are 2 variations of strategy done by the lecturers at this stage. In the implementation the stages are as shown in Table 1 follows.

Table 1

Variations of Lecturers' Strategies at the Writing Stage

\begin{tabular}{ll}
\hline Variation 1 (done by 2 lecturers) & Variation II (done by 3 lecturers) \\
\hline $\begin{array}{l}\text { 1. Forming groups and assigning students } \\
\text { to discuss the result of information }\end{array}$ & $\begin{array}{l}\text { 1. The lecturer assigns the students to make a } \\
\text { summary of main ideas from various sorces }\end{array}$ \\
$\begin{array}{ll}\text { literacy that they have done } & \text { 2. Forming groups to discuss main ideas } \\
\text { obtained. }\end{array}$ \\
$\begin{array}{ll}\text { Making a summary of the main ideas } \\
\text { from various sources in a group to }\end{array}$ & $\begin{array}{l}\text { 3. Organizing main ideas together to makine } \\
\text { new information }\end{array}$ \\
$\begin{array}{ll}\text { 3. Comparing information obtained in a } \\
\text { group }\end{array}$ & $\begin{array}{l}\text { 4. Comparing information obtained together } \\
\text { with that before }\end{array}$ \\
\hline
\end{tabular}

Table 1 shows different sequences in forming groups. In variation 1, the group formation was done at the beginning. In the first variation, the grouping was done at the 
first stage. This was done by the lecturers with the aim of making the students discuss first. Various types of information obtained before writing main ideas obtained. While in variation II, the grouping was done after the students organized new main ideas from information literacy activities individually. This strategy was chosen by the lecturers in order the students became responsible for the result of information literacy. The grouping for discussion was done in order the students could discuss by showing data and avoiding to miss any information. The difference in strategy selection is something that is reasonable in learning because certain factors are considered (Ismaji \& Imami, 2018).

\section{6) Communicating results (Share)}

At this stage the students communicated the result of synthesis that had been done by asking for comments from other friends. Before the students presented the result of information literacy that has been arranged, the lecturer started to remind students to quote information with copy rights correctly and to write their references basically. From the results of presentation and discussion, the lecturer could know the students' ability and helped the students orient the skill and ability that were expected from the students. This step conforms to the fifth step in The Big 6 information literacy model, i.e., synthesis (Eisenberg, et. al., 2010).

The six steps of phenomenon text-based information literacy that have been implemented are a new procedure in information literacy models. This procedure is different from the previous procedures, such as The Big 6, Empowering 8, Seven Pillars, and The Seven Faces of Information Literacy. The six steps in this study put more stress on the attempt to attract nterest and develop a positive attitude toward language. Henceforth, these six steps will be called as six steps of phenomenon information literacy. This model provides an added value to information literacy teaching that generally only stresses on information acquisition. This study shows how information can be directed in addition to drawing interest to learn, it also develops students' attitude. The result of observation shows that the students seemed very enthusiastic in searching information that was related to the phenomenon being discussed. In short, the steps in six steps of phenomenon information literacy can be shown as follows.

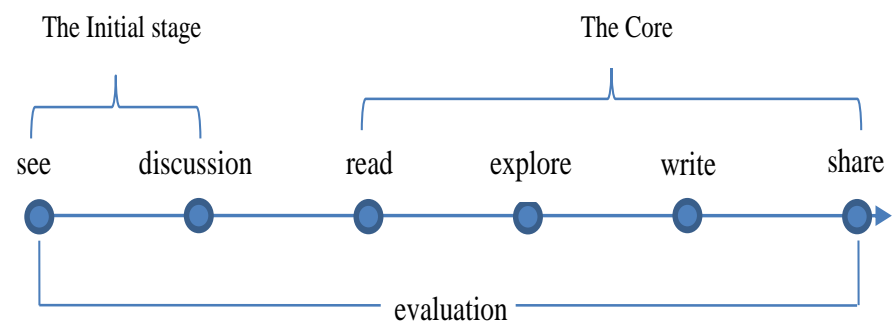

Figure1

Six Steps of Phenomenon Information Literacy 
Figure 1 shows that the evaluation process in this model is done at every stage. The evaluation is done by the lecturer and students. The lecturer evaluates to monitor the activities done by the students and to give guidance if there is any constraint in the activities, while the evaluation by the students is in the form of the determination of focus and direction of the phenonenon discussed. Stages see and discussion form the initial stage or the opening of the lesson to prepare the students for the topic that will be discussed. This stage is an important stage to develop the students' interest and to draw their attention (Dahar, 2011). To achieve this objective, the lecturer's ability in determining a phenomenon is critical at this stage. The next four stages are the core stages of teaching. These stages are aimed at enhancing the students' interest in the phenomenon with the increasingly greater amount of information owned. It is also with this information that a positive attitude is developed. At the end of the teaching, the lecturer and the students do evaluations. At this stage the lecturer gives reinforcement to the positive attitudes that come up and minimize attitudes that are not expected the reinforcements given are in the form of explanations for the phenomena or praises for an attitude.

The students' responses to the phenomenon text-based information literacy in Indonesian language teaching

To know the students' responses questionnaires were distributed to the students. The questionnaire contains statements that are related to the students' interest and language attitude. The results obtained from the questionnaire are as follows.

Table 2

Students' Response toward the Learning Activity

\begin{tabular}{lllll}
\hline Statement No. & Very happy (\%) & Happy $(\%)$ & Less Happy $(\%)$ & Unhappy $(\%)$ \\
\hline 1 & 83.77 & 13.91 & 2.32 & 0 \\
\hline 2 & 65.23 & 33.44 & 1.32 & 0 \\
\hline 3 & 89.74 & 7.28 & 2.98 & 0 \\
\hline 4 & 86.09 & 12.58 & 1.32 & 0 \\
\hline 5 & 76.49 & 20.20 & 3.31 & 0 \\
\hline 6 & 66.56 & 30.79 & 2.65 & 0 \\
\hline 7 & 68.21 & 27.81 & 3.97 & 0 \\
\hline 8 & 85.10 & 13.25 & 1.66 & 0 \\
\hline Total & 77.65 & 19.91 & 2.44 & 0 \\
\hline
\end{tabular}

Table 2 shows that the students' responses to information literacy in Indonesian language teaching fell into the positive category. This can be seen from the total of percentages of very happy responses of $77.65 \%$ and that of happy responses of $19.91 \%$. Thus, $97.56 \%$ of the students gave positive responses to the teaching, the rest, or $2.44 \%$ said that they were less happy and none of them said that they were not happy to learn. The total of the positive responses shows that the students were interested in learning and started to show a positive attitude toward Indonesian language. Results show that six steps of phenomenon information literacy is effective in enhancing the students' interest to learn. 
The result of this study agrees with the result of the study conducted by Hanurawan (2013) which showed that the students' interest in learning is a controversial issue. In addition, the use of phenomenon text also helps the students to develop their critical thinking ability. The result of the study also has a positive impact on their attitude toward Indonesian language. This reminds us of the result of the study by Dewantara (2017) that found various deviations in language usage viewed from word and sentential aspects. Through phenomenon text-based information literacy, the problems can be overcome. In the teaching it appeared that the deviations in the usage became less and less frequent. The students became increasingly aware of the language rules and sociocultural norms. This finding is confirmed by the result of a survey that showed the growth of love, pride, and awareness of the norm in the students.

The conception of phenomenon text-based information literacy fits well with the concept of meaningful learning pointed out by David Ausubel. According to him, new phenomena acquired through learning are acquired by an individual through learning and are connected to the already acquired structure of knowledge acquired before (Dahar, 2011). Through phenomenon text, the students construct their values and attitudes. This is based on the constructivist's idea that teaching is not a process of transmitting information, but a process of constructing knowledge in the students. Suparmo (1997) and Bruce (2004) explain that in the constructivist philosophy, the function of a teacher is as mediator and facilitator that has the task to prepare new experiences, questions or something that can simulate the students' curiosity, to monitor, evaluate and decide whether the new knowledge that has been constructed by the students is suitable or can be used to overcome the existing problems.

The six steps of phenomenon information literacy has been taken advantages when viewed from the teacher's functions in the constructivist philosophy. The lecturer in this procedure acts as mediator and facilitator to create stimuli through phenomena such as at the first step in the teaching procedure in the six steps of phenomenon information literacy. The lecturer gives a stimulus to direct the students and focus their attention to the objective of the teaching. The students' attention on the phenomena becomes more intensive at the second step in the six steps of phenomenon information literacy, that is at the discussion of the phenomenon stage. In the theory of attitude change model of Hovland, et al (1953) it is explained that attention that is aroused will form understanding and reception of the phenomenon object that is being discussed. At the third stage, or reading phenomenon text, and the fourth stage, or searching various forms of information, an increase in intensity of attention and the understanding of the phenomenon occur. At the third stage, or reading a phenomenon text, and at the fourth stage, searching various types of information, an increase in intensity of attention and understanding of the phenomenon. At the fifth stage, the students write the result of their understanding. At this stage, reception of the phenomenon also occurs. Finally, at the sixth stage, the students communicate the result and discussion again. The lecturer once again plays the role of a moderator and facilitator at this stage. 


\section{CONCLUSION}

The attempt to enhance interest and language attitude was made in six steps. The six steps are called as six steps of phenomenon information literacy consisting of 1) Communicating problems in the form of phenomena that occurred in the society (shown through pictures and videos), 2) discussing the phenomenon, 3) reading phenomenon text, 4) searching information from various sources, 5) writing the results of searching of phenomenon, 6) communicating the results. These six steps are different from the existing information literacy procedures. The advantage of the procedure in the six steps of phenomenon information literacy is in its emphasis on the effort to arouse interest and develop a positive attitude. These six steps contain a simple procedure and enable the implementation of information literacy from the lowest level of education to the tertiary level. To make this possible, a try-out of this new procedure needs to be done to see its significance in enhancing the student's interest and developing the student's positive attitude.

The students' response to the six steps of phenomenon information literacy is positive. It means that the six steps of phenomenon information literacy makes the students interested in learning. The positive attitude of the students can also be enhanced with this procedure. This can be seen from the results of the observation and the survey on the aspects of love, pride, and awareness of language norms. This study gives us a guideline on how to make use of phenomenon texts that are controversial in nature as an attempt to arouse attention and develop positive attitude toward language. This is obviously important for the countries whose attitude of their people is still low toward their own languages. This procedure is also suitable for use at schools with a large class. In this situation, the teaching uses the collaborative learning model.

\section{REFERENCES}

Abrar, A. (2015). Pembelajaran sejarah dan teacherpreneur. Jurnal Pendidikan Sejarah, $4(2), 1-12$.

Anda, U. K. (2017). Pengaruh pendekatan pembelajaran socioscientific issues (SSI) terhadap kemampuan berpikir kritis siswa pada materi pemanasan global. Ilmu Pendidikan.

Apriyani, M. (2006). Literasi informasi pemustaka: studi kasus di perpustakaan umum daerah provinsi DKI jakarta. Jakarta: Universitas Indonesia. Fakultas Ilmu Pengetahuan Budaya.

Bainton, T. (2001). Information literacy and academic libraries: the sconul approach (Uk/Ireland). Libraries and librarians: making a difference in the knowledge age. Council and General Conference: Conference Programme and Proceedings $\left(67^{\text {th }}\right.$, Boston, Ma, August 16-25, 2001), (5), 1-9.

Balfas, A. (2008). Mengembangkan kemampuan literasi dan berfikir kritis siswa melalui pembelajaran sastra berbasis konteks. Linguistika, 15(29), 154-163. 
Boyer, E. L. (1997). New technologies and the public interest. Selected Speeches 19791995. Princeton, N.J.: Carnegie Foundation for The Advancement of Teaching.

Breivik, P. S., \& Gee, E. G. (1989). Information literacy: revolution in the library. Ace Oryx.

Bruce, C. S. (2004). information literacy as a catalyst for educational change a background paper. Proceedings "Lifelong Learning: Whose Responsibility and What Is Your Contribution?", The 3rd International Lifelong Learning Conferencethe 3rd International Lifelong Learning Conference, 8-19.

Bundy, A. (2004). Australian and New Zealand information literacy framework. Principles, standards and practice, 2.

Byford, J., Lennon, S., \& Russell, W. B. (2009). Teaching controversial issues in the social studies: A research study of high school teachers. The Clearing House: A Journal of Educational Strategies, Issues and Ideas, 82(4), 165-170.

Clarke, P. (2005). Teaching Controversial issues: A four-step classroom strategy for clear thinking on controversial issues. BCTF/CIDA Global Classroom Initiative 2005.

Dahar, R. W. (2011). Teori teori belajar dan pembelajaran. Jakarta: Airangga.

Demirci, C. (2017). The effect of active learning approach on attitudes of $7^{\text {th }}$ grade students. International Journal of Instruction, 10(104), 129-144. Https://Doi.Org/10.12973/Ijji.2017.1048a

Dewantara, I. P. M. (2017). The deviation of words aspects and sentences among students'speech. Jurnal Pendidikan dan Pengajaran, 50(1), 36-44.

Dewantara, I. P. M. (2017). Stake evaluation model (countenance model) in learning process bahasa indonesia at ganesha university of educational. International Journal of Language and Literature, 1(1), 19-29.

Dibia, I KT., Dewantara, \& Sri Indriani. 2015. Evaluasi pembelajaran MPK Bahasa Indonesia di Universitas Pendidikan Ganesha. Laporan Penelitian

Eisenberg, M., Johnson, D., \& Berkowitz, B. (2010). Information, communications, and technology (ict) skills curriculum based on the big6 skills approach to information problem-solving. Library Media Connection, 28(6), 24.

Folk, A. L. (2016). Information literacy in postsecondary education in the United Kingdom, the United States, Australia, and New Zealand. portal: Libraries and the Academy, 16(1), 11-31.

Frau-Meigs, D. (2017). Transliteracy as the new research horizon for media and information literacy. Medijske studije, 3(6). 
Gelisli, Y., Baidrahmanov, D. K., Beisenbaeva, L., \& Sultanbek, M. (2017). Determination of the high school students' attitudes towards their teachers. International Journal of Instruction, 10(4), 361-378.

Gewati, M. (2017). Minat baca Indonesia ada di urutan ke-60 dunia. Dalam http://bit. ly/2jmaCbv, diakses, 1 .

Gipayana, M. (2016). Pengajaran literasi dan penilaian portofolio dalam konteks pembelajaran menulis di SD. Jurnal Ilmu Pendidikan, 11(1).

Grafstein, A. (2002). A discipline-based approach to information literacy. The Journal of Academic Librarianship, 28(4), 197-204.

Hadiya, I., Halim, A., \& Adlim, A. (2015). Pengembangan modul pembelajaran suhu dan kalor berbasis masalah untuk SMA dalam upaya meningkatkan minat belajar siswa. Jurnal Pendidikan Sains Indonesia, 3(1), 81-92.

Hand, M., \& Levinson, R. (2012). Discussing controversial issues in the classroom. Educational Philosophy and Theory, 44(6), 614-629.

Hanurawan, F. (2013). Sikap Mahasiswa terhadap penggunaan diskusi isu-isu kontroversial. Jurnal Ilmu Pendidikan, 18(2).

Hasugian, J. (2009). Urgensi literasi informasi dalam kurikulum berbasis kompetensi di perguruan tinggi. Pustaha, 4(2), 34-44.

Hovland, C., Janis, I., \& Kelly, H. (1953). Communication and persuasion. New Haven, CT: Yale University Press.

Ibrahim, M. L., \& Jimoh, A. O. (2013). Sustainable teacher education in Nigeria through information literacy in the 21 st century. Mediterranean Journal of Social Sciences, 4(12), 75

Ismajli, H., \& Imami-Morina, I. (2018). Differentiated instruction: Understanding and applying interactive strategies to meet the needs of all the students. International Journal of Instruction, 11(3), 207-218. Https://Doi.Org/10.12973/Iji.2018.11315a

Kong, S. C. (2014). Developing information literacy and critical thinking skills through domain knowledge learning in digital classrooms: An experience of practicing flipped classroom strategy. Computers \& Education, 78, 160-173.

Latief, A. S. (2016) Kemampuan literasi informasi dosen menelusur informasi untuk menunjang kompetensi dalam pengajaran di STIE Bina Bangsa Serang-Banten.

Marcus, A. S., \& Stoddard, J. D. (2009). The inconvenient truth about teaching history with documentary film: Strategies for presenting multiple perspectives and teaching controversial issues. The Social Studies, 100(6), 279-284. 
Memduhoğlu, H. B., Kotluk, N., \& Yayla, A. (2017). The effect of focus group discussions on pre-service teachers' teaching experiences and practices: A mixed methods study. international journal of instruction, 10(104), 273-292. Https://Doi.Org/10.12973/İji.2017.10416a

Miles, M. B., \& Huberman, A. M. (1992). Analisis data kualitatif: buku sumber tentang metode-metode baru. Jakarta: U1 Press.

Mustami, M. K., Makassar, N. A., \& Safitri, D. (2018). The effects of numbered heads together-assurance relevance interest assessment satisfaction on students' motivation. International Journal of Instruction, 11(3), 123-134. Https://Doi.Org/10.12973/Iji.2018.1139a

Mutmainah, S. (2008). Pengaruh penerapan metode pembelajaran kooperatif berbasis kasus yang berpusat pada mahasiswa terhadap Efektivitas pembelajaran akuntansi keperilakuan.

Nesset, V. (2015). Using empirical data to refine a model for information literacy instruction for elementary school students. Information Research: An International Electronic Journal, 20(1), n1.

Novianti, N. (2017). Teaching Character Education to College Students Using Bildungsromans. International Journal of Instruction, 10(4), 255-272. Https://Doi.Org/Https://Doi.Org/10.12973/Iji.2017.10415a

Nurohman, A. (2014). Signifikansi literasi informasi (information literacy) dalam dunia pendidikan di era global. Jurnal Kependidikan, 2(1), 1-25.

Oulton, C., Dillon, J., \& Grace, M. M. (2004). Reconceptualizing the teaching of controversial issues. International Journal of science education, 26(4), 411-423.

Owusu-Ansah, E. K. (2004). Information literacy and higher education: Placing the academic library in the center of a comprehensive solution. The Journal of academic librarianship, 30(1), 3-16.

Pattah, S. H. (2014). Literasi informasi: peningkatan kompetensi informasi dalam proses pembelajaran. Khizanah al-Hikmah Jurnal Ilmu Perpustakaan, Informasi, dan Kearsipan, 2(2), 108-119.

Pranowo \& Herujiyanto, A. (2015). Faktor dan strategi pengembangan budaya baca melalui membaca pemahaman mahasiswa. Linguistik Indonesia, 33(2), 153-171.

Prihantoro, E. (2016). Upaya meningkatkan prestasi belajar IPS melalui model pembelajaran assurance relevance interest assesment satisfaction (arias) pada siswa kelas IV SD I Pedes Sedayu Bantul DIY tahun ajaran 2015/2016 (Doctoral dissertation, Universitas PGRI Yogyakarta).

Pujiono, S. (2012). Berpikir Kritis dalam Literasi membaca dan menulis untuk memperkuat jati diri bangsa. Prosiding PIBSI XXXIV, 778-783. 
Rader, H. B. (1991). Information literacy: a revolution in the library. $R Q, 31(1), 25-30$.

Saefudin, A. (2013). Analisis pembelajaran sejarah isu-isu kontroversial di SMA (Studi Kasus di SMA Negeri 1 Banyumas) (Doctoral dissertation, UNS (Sebelas Maret University)).

Shao, X., \& Purpur, G. (2016). Effects of information literacy skills on student writing and course performance. The Journal of Academic Librarianship, 42(6), 670-678.

Subandiyah, H. (2017). Pembelajaran literasi dalam mata pelajaran bahasa indonesia. Paramasastra, 2(1).

Suwana, F., \& Lily. (2017). Empowering indonesian women through building digital media literacy. Kasetsart Journal of Social Sciences, 38(3), 212-217. Https://Doi.Org/10.1016/J.Kjss.2016.10.004

Subandiyah, H. (2017). Pembelajaran literasi dalam mata pelajaran bahasa indonesia. Paramasastra, 2(1).

Sumardiansyah, S. (2015). Paradigma dalam pembelajaran sejarah kontroversi. Jurnal Pendidikan Sejarah, 4(2), 77-88.

Suparmo, Paul. (1997). Filsafat konstruktivisme dalam pendidikan.Yogyakarta: Kasinisius.

Techataweewan, W., \& Prasertsin, U. (2017). Development of digital literacy indicators for thai undergraduate students using mixed method research. Kasetsart Journal of Social Sciences, 37(2), 215-221. Https://Doi.Org/10.1016/J.Kjss.2017.07.001

Yulaningsih. (2014). Literasi indonesia sangat rendah. Republika Online.

Yulianita, U. (2014). Korelasi antara penerapan literasi informasi siswa kelas VII dengan nilai tugas bahasa indonesia di SMP N 5 Yogyakarta. 